\title{
PEMANFAATAN LIMBAH JERAMI SEBAGAI SOUVENIR YANG BERNILAI ARTISTIK
}

\author{
Sutriyanto \\ Jurusan Kriya \\ Fakultas Seni Rupa dan Desain ISI Surakarta \\ Email: su3.artsih@gmail.com \\ Muhammad Arif Jati Purnomo \\ Jurusan Kriya \\ Fakultas Seni Rupa dan Desain ISI Surakarta \\ Email: ariefj4ti@gmail.com \\ Rd. Ernasthan Budi Prasetya \\ Jurusan Desain \\ Fakultas Seni Rupa dan Desain ISI Surakarta \\ Email:Ernasthan@isi-ska.ac.id
}

\begin{abstract}
Abstrak
Limbah jerami merupakan salah satu material yang sangat melimpah didaerah pedesaan, terutama di daerah yang menjadikan tanaman padi menjadi tanaman pokok dalam bercocok tanam. Di daerah pertanian yang subur dengan sistim irigasi yang lancar sepanjang tahun, mereka mampu panen padi tiga kali selama satu tahun, artinya tiap tiga bulan mereka panen. Jerami adalah batang padi sisa dari panen yang dibiarkan tidak dimanfaatkan selain sebagai makanan ternak atau sebagai media untuk tumbuh jamur merang. Berangkat dari latar belakang tersebut maka timbul satu permasalahan untuk mengangkat material sisa hasil panen padi yang melimpah tiap tahun ini menjadi lebih bernilai guna, baik secara material maupun fungsional. Tujuan dari pengabdian kepada masyarakat ini adalah memberikan pelatihan atau pengetahuan kepada masyarakat tentang alternative pemanfaatan limbah jerami untuk souvenir yang lebih bernilai ekonomi. Metode yang digunakan menggunakan metode pelatihan dan pendampingan sampai menghasilkan produk yang layak jual. Hasil dari kegiatan ini berupa prototype atau model souvenir yang artistic yang memiliki nilai jual yang lebih.
\end{abstract}

Kata kunci: Limbah, Jerami, Souvenir.

\begin{abstract}
Waste straw is one of the most abundant materials in rural areas, especially in areas that need rice to become a staple crop in farming. In fertile agricultural areas with an irrigation system throughout the year, they are able to harvest rice three times for one year, meaning every three months of their harvest. Straw is rice stalks left over from harvest that are left not used other than as animal feed or as a medium for growing straw mushrooms. Starting from this background, a problem arises to raise the abundant residual material of rice yields each year to become more useful, both materially and functionally. The purpose of community service is to provide training or knowledge to the
\end{abstract}


community about alternative uses of waste for souvenirs of more economic value. The method used uses training and assistance methods to produce products that are worth selling. The results of this activity contain prototypes or models of artistic souvenirs that have more selling points.

Keywords: Waste, Straw, Souvenir.

\section{PENDAHULUAN}

Jerami adalah bagian batang padi yang sudah ditebang untuk diambil padinya. Pada umumnya jerami dimanfaatkan untuk makanan ternak, untuk pupuk dan media tanamjamur merang. Limbah jerami ini akan melimpah ketika masa panen padi berlangsung, sehingga karena melimpahnya jerami kadang kurang terpikirkan pemanfaatannya secara efektif sebagai produk yang mampu melahirkan pemikiran-pemikiran kreatif sehingga memiliki daya jual yang lebih. Limbah jerami merupakan limbah hasil pertanian dari sisa panen padi yang belum banyak dimanfaatkan secara maksimal dan jumlahnya cukup banyak pada masamasa tertentu, terutama pada saat pasca panen. Seperti halnya yang ada di Dusun Klebrekan, Desa Tamansari yang terletak di Kecamatan Kerjo, Kabupaten Karanganyar yang sebagian besar masyarakatnya memiliki mata pencaharian sebagai petani padi, sehingga limbah jerami yang dihasilkan cukup banyak.

Limbah jerami sebenarnya dapat dimanfaatkan sebagai pembenah tanah dan sebagai pakan ternak, namun belum banyak masyarakat yang mengetahui manfaat tersebut, terkadang petani memanfaatkannya sebagai bahan bakar saat pembakaran batu bata atau genteng yang dilakukan di daerah sawah. Bagi para pedagang telur dan buah, jerami juga dapat dimanfaatkan sebagai alas agar barang dagangan mereka tidak mudah rusak akibat goncangan. Biasanya petani hanya menumpuknya dipinggir sawah dan membiarkannya busuk, sehingga dapat digunakan sebagai pupuk tanaman lainnya.

Limbah padi atau jerami tersebut ternyata dapat dimanfaatkan sebagai bahan dasar kerajinan yang cukup unik dan artistik. Produk kerajinan dari jerami masih tergolong langka, sehingga sangat berpotensi untuk dapat dikembangkan. Untuk masyarakat yang tinggal di dekat persawahan atau pasar tentunya tidak menemui kesulitan dalam mencari limbah jerami dan tidak perlu mengeluarkan banyak dana. Pemanfaatan limbah jerami menjadi produk kerajinan memiliki nilai lebih di bidang ekonomi. Sekarang ini orang sudah mulai menyenangi produk kerajinan yang berasal dari bahan jerami, karena selain menarik juga ramah lingkungan. Maka dapat dikatakan bahwa peluang usaha dari limbah jerami dapat menguntungkan.

Bagian-bagian jerami memiliki keunikan masing-masing, yaitu dapat dimanfaatkan sebagai bahan dasar kerajinan, dari mulai batang padi, ranting padi, selongsong padi dan gabah kosong yang telah dirontokkan dari ranting padi. Berkenaan dengan permasalahan tersebut maka perlu strategi dalam hal ini untuk menciptakan produk khas atau brand Desa Wisata Tamansari lewat penggalian kantong-kantong budaya di masyarakat desa, dengan penciptaan ikon daerah nantinya dapat menyerap wisatawan dan stakeholder atau investor pada umumnya. Selain menciptakan peluang pengembangan potensi-potensi lainnya juga untuk menarik wisatawan tentunya perlu mendorong dan memajukan ekonomi UKM-UKM yang terbina sarat dengan bakat dan potensi yang dimiliki di setiap dusun di Desa Tamansari. Maka proses penciptaan ini nantinya menjadi salah satu capaian yang dapat memberikan stimulus yang ada di Desa Tamansari Kecamatan Kerjo Kabupaten Karanganyar dengan kajian tentang kondisi ekonomi dan sosial-budaya masyarakatnya

Salah satu potensi adalah pemanfaatan limbah jerami secara optimal penggarapan dan pemasaranya. Maka dengan kerjasama dengan 


\section{Abdi Seni Jurnal Pengabdian Kepada Masyarakat}

intistusi lewat PPM berharap nantinya mampu memberikan stimulant bagi masyarakat untuk lebih mencintai dan melestarikan seni tradisi sehingga mampu menciptakan produk dan peluang ekonomi bagi masyarakat desa dan sekitarnya.

\section{Permasalahan Mitra:}

1. Kemampuan masyarakat desa Tamansari Kerjo Karanganyar yang sangat minim dalam membuat desain terlebih mewujudkan dalam sebuah produk seni, dalamupaya memanfaatkan limbah jerami.

2. Minimnya kemampuan mengeksplorasi material alam guna dijadikan produk kriya.

3. Sangat terbatasnya akan informasi yang berkaitan dengan pengelolaan sumber daya alam sekitar yang mampu menghidupi dan meingkatkan perekonomian masyarakat.

4. Disamping itu juga minimnya kemauan bekerja mandiri melalui wirausaha bagi masyarakat desa Tamansari Kerjo Karanganyar, khusunya para pemudanya. Sebagian besar pemuda atau masyarakat setempat hanya mengandalkan bercocok tanam, dan sebagian besar pemudanya, lebih nyaman keluar desa untuk mencari kerja ke kota daripada hidup di desa.

\section{KAJIAN LITERATUR}

Limbah merupakan buangan atau material sisa yang dianggap tidak mempunyai nilai yang dihasilkan dari suatu proses produksi, baik industri atau juga domestik (rumah tangga). Terdapat juga yang mengatakan bahwa definisi dari limbah ini ialah semua material sisa atau buangan yang berasal dari proses teknologi atau juga dari proses alam yang mana kehadirannya itu tidak berguna bagi lingkungan serta tidak mempunyai nilai ekonomis. Pada dasarnya berbagai jenis limbah ini dihasilkan oleh kegiatan atau aktivitas manusia, baik itu dari kegiatan atau aktivitas industri atau juga domestik (rumah tangga) dan memiliki dampak buruk terhadap lingkungan dan juga tentu bagi kesehatan manusia. Pengertian limbah adalah sisa atau hasil sampingan dari kegiatan manusia dalam upaya memenuhi kebutuhan hidupnya (Susilowarno,2007;18). Lain halnya dengan Susilowarna, definisi limbah menurut Karmana adalah sisa atau sampah dari suatu proses kegiatan manusia yang dapat menjadi bahan polutan di suatu lingkungan $(2007 ; 23)$.

Demikian halnya dengan limbah jerami yang juga merupakan sisa atau buangan dari hasil pertanian (batang padi) yang dianggap tidak memiliki nilai ekonomis. Selama ini masyarakat pedesaan menganggap bahwa limbah jerami hanya difungsikan sebagai makanan ternak saja, atau juga ada sebagian masyarakat yang sudah menggunakan sebagai media tanam jamur merang.

Istilah suvenir berasal dari bahasa Inggris souvenir yang berarti tanda mata; kenang-kenangan; cenderamata https://kbbi.web.id/suvenir. Menurut Nurnitasari yang dimaksud dengan souvenir adalah suatu benda yang identik dengan suatu event daerah tertentu, pada umumnya bentuknya ringkas, mungil serta mempunyai nilai artistik (Nurnitasari, 2009; 114). Sedangkan menurut Prakosa \& Cheon adalah benda yang dibeli yang berfungsi sebagai pengingat akan suatu pengalaman trtentu, diproduksi secara komersial dan seringkali dihubungkan secara universal dengan turisme (2013; 24). Jadi souvenir atau suvenir adalah suatu upaya kreatif dari seseorang untuk membuat sebuah barang yang mampu menjadi pengingat sebuah lokasi (biasanya tempat wisata) yang pernah dikunjungi. Biasanya souvenir berupa barang yang praktis, unik, menarik, mudah dibawa, dan harganya relative murah. Bentuk dari souvenir pada umumnya mengacu pada karakter atau cirri khas daerah atau lokasi tempat wisata tersebut, misalnya tempat wisata pantai, maka sovenirnya kebanyakan terbuat dari flora-fauna atau lingkungan pantai seperti hiasan bunga darikerang, miniature kapal nelayan/pinisi dan sebagainya. 


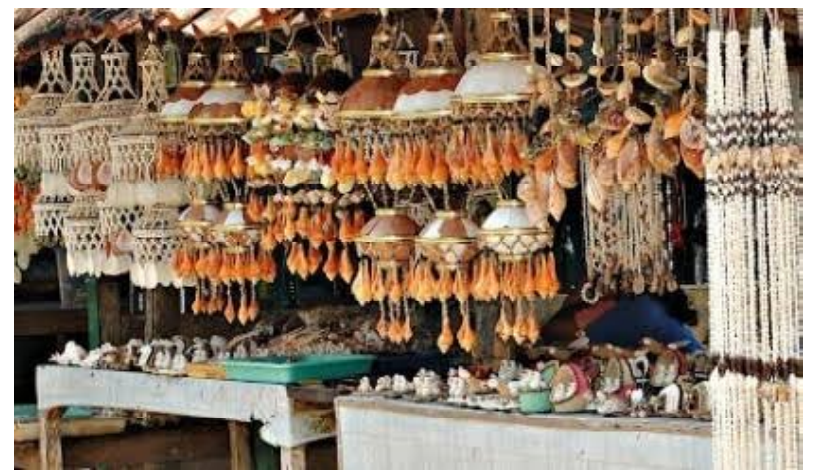

Gambar 1. Berbagai jenis souvenir khas pantai yang terbuat dari kerrang

(https://bisnisukm.com/usaha-kreatifmemproduksi-cinderamata-khas-pantai.html)

Istilah artistik pada umumnya digunakan untuk menyatakan segala sesuatu yang bersifat seni atau memiliki nilai seni. Sebagai contoh misalnya lukisan, atau sebuah pagelaran sendratari, pertunjukan music dan lain sebagainya. Semuanya memiliki nilai atau value keindahan bagi audience untuk melihat atau mendengarkannya. Menurut Harianja $(2002 ; 16)$ menyatakan bahwa yang dimaksud dengan artistik adalah segala sesuatu yang berkaitan dengan kreasi artistik, ekspresi emosi, ekspresi diri dan kegiatan individualistik. Menurut KBBI, artistik berarti mempunyai nilai seni; bersifat seni; mempunyai bakat dalam kesenian; mempunyai rasa seni. https://kbbi.web.id/artistik.

Tidak hanya benda-benda atau material atau kegiatan kesenian saja yang dikatakan memiliki nilai artistik, akan tetapi benda-benda diluar produk senipun juga dapat memiliki sisi artistik atau seni di dalamnya. Sebagai contoh cangkir untuk minum yang terdapat ornament atau lukisan di pinggirnya, atau juga kap lampu dari rotan yang dirancang sedemikian rupa sehingga terlihat bias-bias cahaya yang indah dan menarik.

Dari beberapa definisi di atas dapat disimpulkan bahwa yang dimaksud dengan pemanfaatan limbah jerami sebagai souvenir yang bernilai artistic adalah bahwa sisa hasil pertanian (padi) yang biasa disebut dengan jerami itu mampu dikembangkan menjadi sebuah produk yang indah, yang nantinya bisa digunakan sebagai cinderamata khas daerah pedesaan.

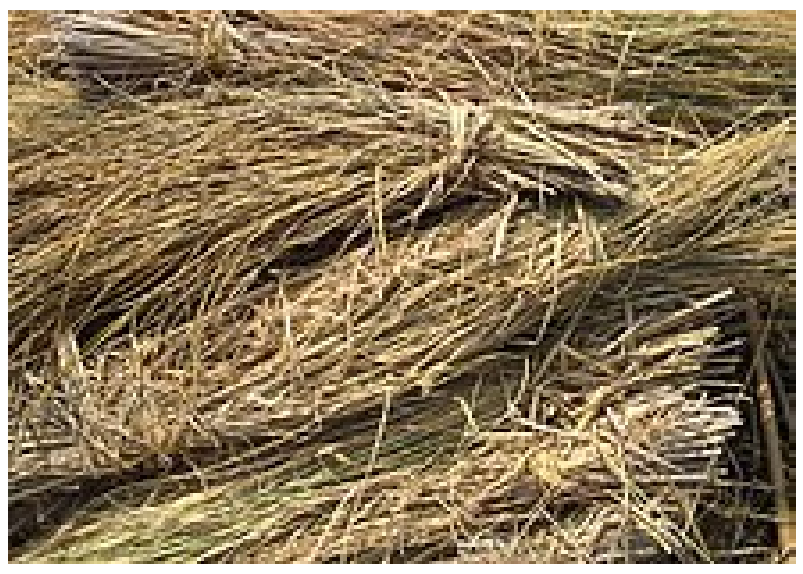

Gambar2. Limbah jerami yang menumpuk (Foto : Sutriyanto, 2019)

\section{METODE}

Metode penelitian yang digunakan meminjam teori kreasi artistik dengan pendekatan proses dengan risert emik sebagai strategi pengumpulan data yang dipergunakan dalam proses kreatifartistik, meliputieksperimen, perenungan, dan pembentukan (Dharsono,2016). Dengan langkahlangkah sebagai berikut:

1. Eksperimen merupakan langkah kegiatan yang dilakukan seniman dan/atau disainer dalam melakukan langkah proses kreasi artistic (penciptaan) yaitu meliputi: a). mencoba beberapa alternatif bahan yang sesuai dan cocok dengan ekspresi cipta seni yang anda rancang. b). mencoba beberapa alternative teknik individu yang cocok dengan ekspresi dalam cipta seni yang anda rancang. c). mencoba beberapa alternatif alat yang cocok dengan ekspresi dalam cipta seni yang anda rancang, dan d). Pemilihan konsep visual (tata susun).

2. Eksperimen akan menghasilkan kualitas dalam pemilihan bahan, teknik, alat dan konsep tatasusun yang akan digunakan seniman dalam memvisualisasikan rancangan karyanya.

3. Perenungan merupakan pengembaraan batin sang seniman dalam mencari symbol (metafora). 


\section{Abdi Seni Jurnal Pengabdian Kepada Masyarakat}

Perenungan dilakukan untuk mencari untuk menemukan simbol-simbol (bahasa metafora) yang akan menjadi ikon dalam proses kreatif artistic dalam penciptaan karya seni. Dalam perenungan seniman dan/atau disainer akan menemukan symbol dan/atau metafora. Symbol itu akan dipakai sebagai bahasa ekspresinya, dan kemudian akan digunakan sebagaimotif pokok (utama), motif pendukung dan motif isian. Motif pokok (utama), akan menjadi centre of interest dan yang akan menjadi idiom komunikasi yang yang dibabarkan lewat media dan menjadi ekspresi personalnya. Motif utama merupakan idiom metafora yang memberikan informasi filosofis yang sifatnya sangat individu.

4. Pembentukan merupakan rancangan tatasusun atau komposisi yang dirancang untuk mendapatkan bentuk atau struktur karya. Struktur merupakan komposisi yang akan selalu berkaitan dengan konsep tata susun: (1) kualitas unsur sebagai ikon seni yang dirancang, (2) Prinsip tatasusun (harmoni, kontras, irama (repetisi), gradasi), yang dirancang, (3). azas tata susun meliputi keseimbangan (formal/ informal balance) dan unity) yang dirancang untuk mencapai satu kesatuan (unity). Tata susun tersebut akan menghasilkan dinamika (lembut, sedang, dan kuat), dan dimamika tersebut akan menghasikan suasana tertentu dan/atau kesan tertentu.

\section{PEMBAHASAN}

Pelaksanaan pelatihan pembuatan desain dan produk kriya berbahan utama limbah jerami ini, dilaksanakan di desa Tamansari, tepatnya di di Kecamatan Kerjo, Kab Karanganyar, terutama warga di sekitar kaliBuntung. Pelatihan ini digagas oleh beberapa warga yang menjadi pengurus organisasi di desa setempat, seperti pengurus UKM Omah Kreasi (Wardoyo), ketua tim kreatif Pasar Tradisional Kali Buntung (Karno Galih Pambudi) dan beberapa temannya pengurus karangtaruna Thintir Nusantara. Melalui usulan surat yang di kirimkan ke LPPMPPPM ISI Surakarta.

Tujuan dari diadakannya pelatihan ini, mereka berharap diberikan beberapa pelatihan bagi para perajin bambu yang selama ini telah berproduksi, selain pemanfaatan limbah jerami yang secara lebih maksimal, terutama guna mendukung industry kerajinan yang ada. Harapan lain, akhirnyadari pelatihan ini dapat meramaikan wisata pasar tradisional yang menjadi andalan warga setempat, sebagai pasar yang diperuntukan bertemunya semua warga tamansari. Bahkan pasar ini telah mendapat sorotan dari warga di luar tamansari sabagai pasar wisata yang menyenangkan karena suasananya yang berada disekitar sawah, di tepi sungai Buntung di bawah pepohonankelapa dan tehnis jual beli menggunakan kepengan uang kreweng (uang buatan berasal daripecahan genting).

Bersama warga tersebut diatas yang merupakan penggagas, kegiatan pelatihan ini dapat berjalan lancer. Diawali dengan pencarian data berkeliling kampong, bertemu dengan beberapa perajin, warga petani, hingga ke pemerintah desa Tamansari. Data yang dibutuhkan baik berupa lisan, tulasan, maupun gambar, semua dengan mudah didapatkan. Dibantu beberapa data dari internet, guna mencari referensi produk-produk yang dapat dibuat dengan menggunakan material jerami atau diaplikasikan dengan menggunakan jerami. Maka terciptalah beberapa produk fungsional berbahan jerami yang dapat ditularkan kepada warga peserta pelatihan jerami. Berikut beberapa produk kriya hasil produksi warga Tamansari sebelum diadakan pelatihan.

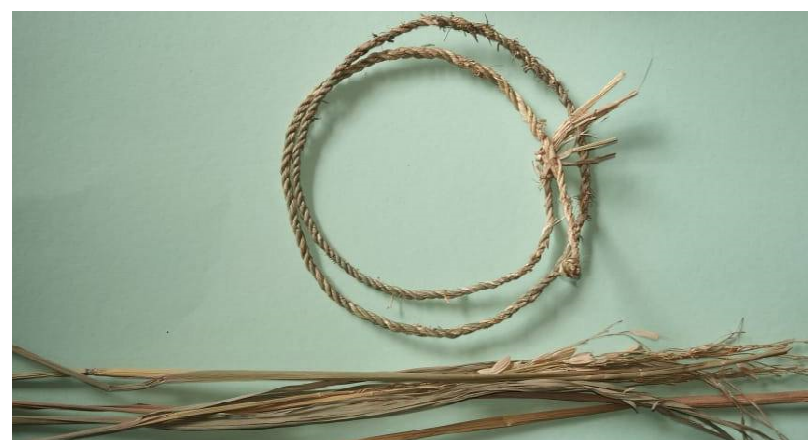

Gambar 3. Tali yang terbuat dari jerami

(Foto : Thea, 2019) 


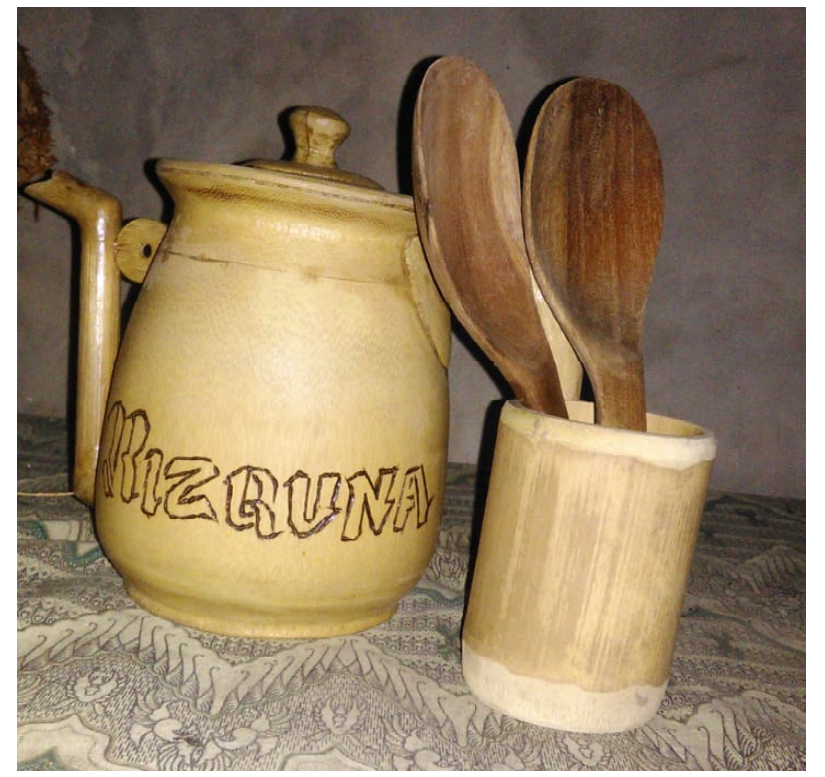

Gambar 4. Beberapa peralatan rumah tangga yang terbuat dari bambu

(Foto: Thea, 2019)

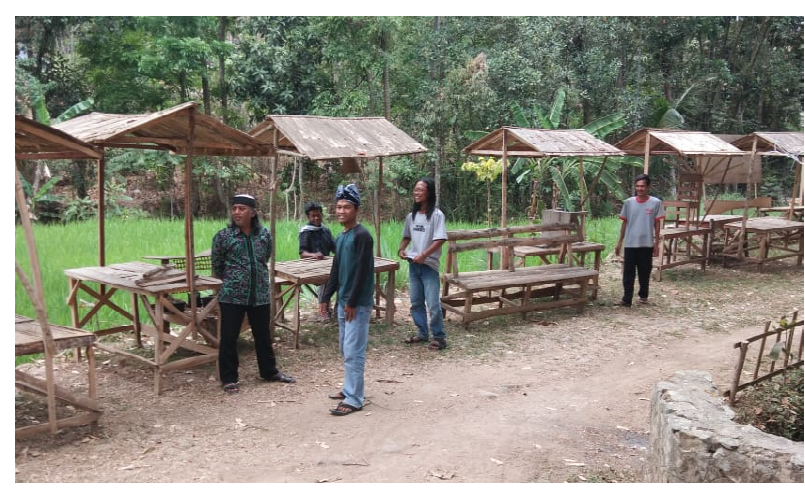

Gambar 5. Pasar tradisional Kali Buntung sebagai tempat menjajakan cinderamata atau souvenir dari limbah jerami.

(Foto: Thea, 2019)

Sebelum dilakukan pelatihan penulis mengadakan pertemuan beberapa kali di beberapa tempat dengan beberapa warga, guna koordinasi kegiatan yang akan dilakukan. Koordinasi sangat diperlukan, guna mempersiapkan berbagai hal, baik itu waktu, material dan materi yang akan disampaikan. Materi yang diberikan tidak hanya berupa teknik pembuatan produk kriya tetapi juga tentang pemasaran produk, terutama pemasaran sacara online.
Pelatihan diikuti oleh 16 orang yang berasal dari beberapa kampung di desa Tamansari. Peserta pelatihan ada yang sebagian dari para perajin bambu ada pula yang berasal warga setempat yang merasa tertarik dalam pelatihan ini. Semua peserta yang terlibat dalam pelatihan ini merupakan warga yang telah dipilih dan dianggap mau serta mampu konsisten mengembangkan produksi kerajinan jerami.

Beberapa material sepertijerami dan bambu telah disediakan oleh warga Tamansari yang menjadi mitra. Diawali dengan pembuatan benang dengan menggunakan jerami baik untuk ukuran besar maupun kecil. Untuk lebih jelas dapat di rundown dibawah ini. Sebelum pelatihan dimulai terlebih dahulu telah dilakukan pertemuan guna keperluan koordinasi.

Sebagaimana direncanakan pada awal pertemuan, bahwa beberapa produk yang akan dibuat lebih bersifat fungsional ketimbang produk yang berfungsi hanya menghias. Ada beberapa hal yang harus dipertimbangkan dalam membuat produk kriya yang mengutamakan nilai fungsi. Louis Sulivan dalam Fictor Papanek mengutarakan bahwasannya dalam membuat produk fungsional harus lebih mengutamakan fungsinya ketimbang bentuknya (Form Follow Function). Demi untuk mengembangkan desain yang baru banyak produsen yang mengutamakan bentuknya ketimbang dungsinya, sehingga dalam penggunaannya justru tidak nyaman, tidak tepat bahkan ada yang tidak bisa digunakan walaupun karya tersebut memiliki unsur artistik yang sangat baik.

Produk kriya merupakan produk yang memiliki unsur kreativitas tinggi, devinisi kreativitas tinggi karena ditinjau dari unsur teknik dalam membuat. Penggunaan teknologi yang berlebihan atau dapat mengurangi kreativitas. Sebagaimana diutarakan oleh Gell, bahwa teknologi tinggi pada sebuah karya seni dilihat dari kemampuan tangan dalam mewujudkan karya tersebut. Di era digital saat ini banyak teknologi yang mampu menggantikan kreativitas tangan. Sebagai cantoh, saat ini sebuah teknologi mesin digital dapat menghasilkan sebuah 
ukuran kayu tanpa menggunakan sentuhan tangan secara langsung. Menggunakan mesin yang biasa disebut dengan CNC (Computer Numerical Control). Sebuah pintu penuh dengan ukiran dapat dihasilkan dalam waktu 2 jam, sedangkan bila dikerjakan dengan menggunakan tangan (dipahat) bisa membutuhkan waktu hingga satu minggu. Demikian secara financial biaya produksi dapat jauh lebih murah, namun bila ditinjau dari segi artistik teknologi, karya tersebut sangat rendah nilai artistiknya.
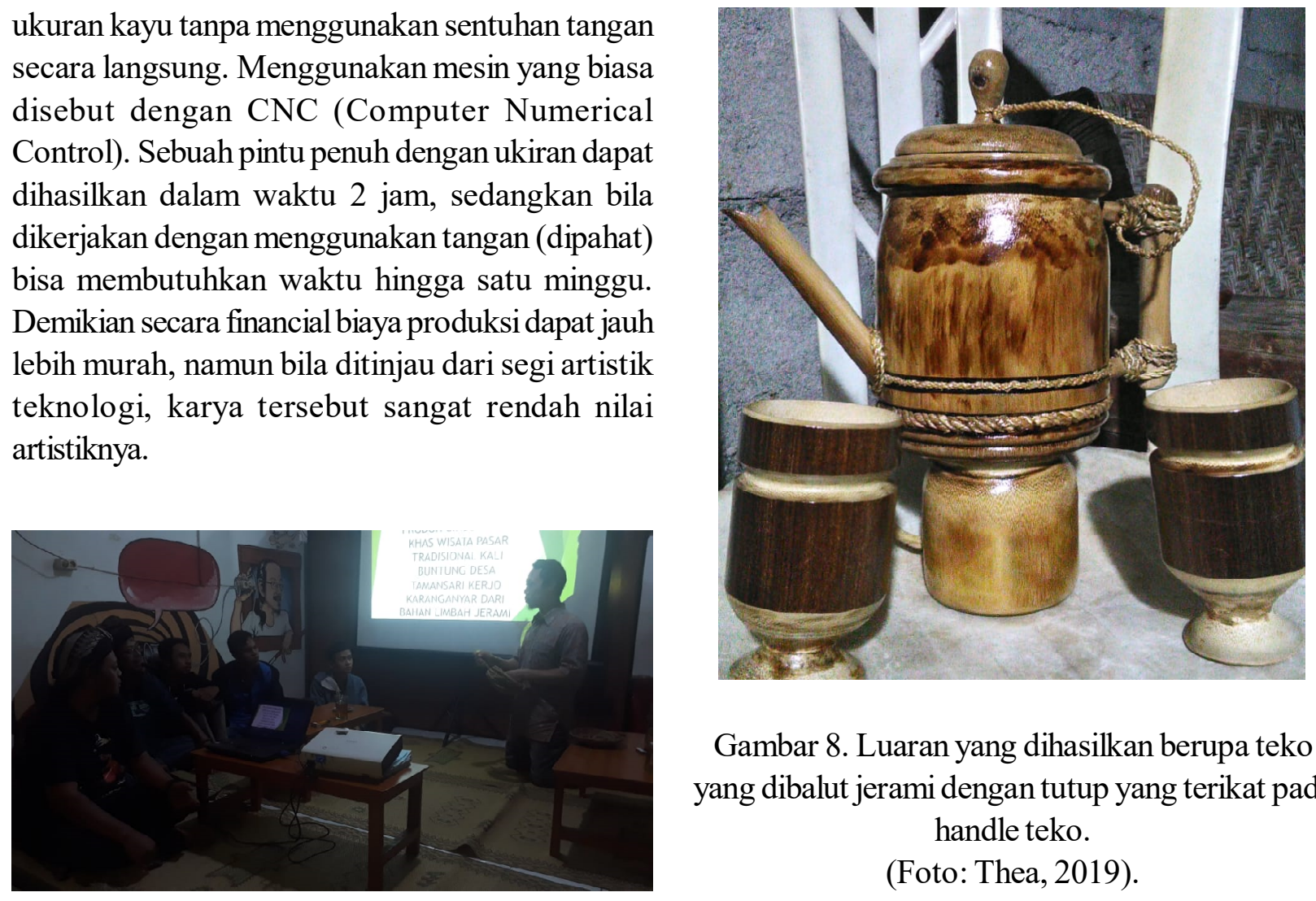

Gambar 8. Luaran yang dihasilkan berupa teko yang dibalut jerami dengan tutup yang terikat pada handle teko.

(Foto: Thea, 2019).

Gambar 6. Suasana pertemuan awal dengan warga

(foto: Thea, 2019)

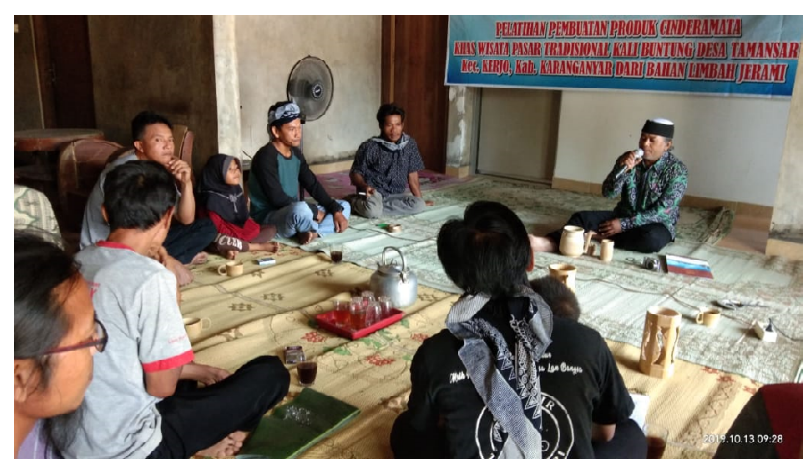

Gambar 7. Pertemuan dengan warga menjelang pelatihan.

(Foto : Thea, 2019)

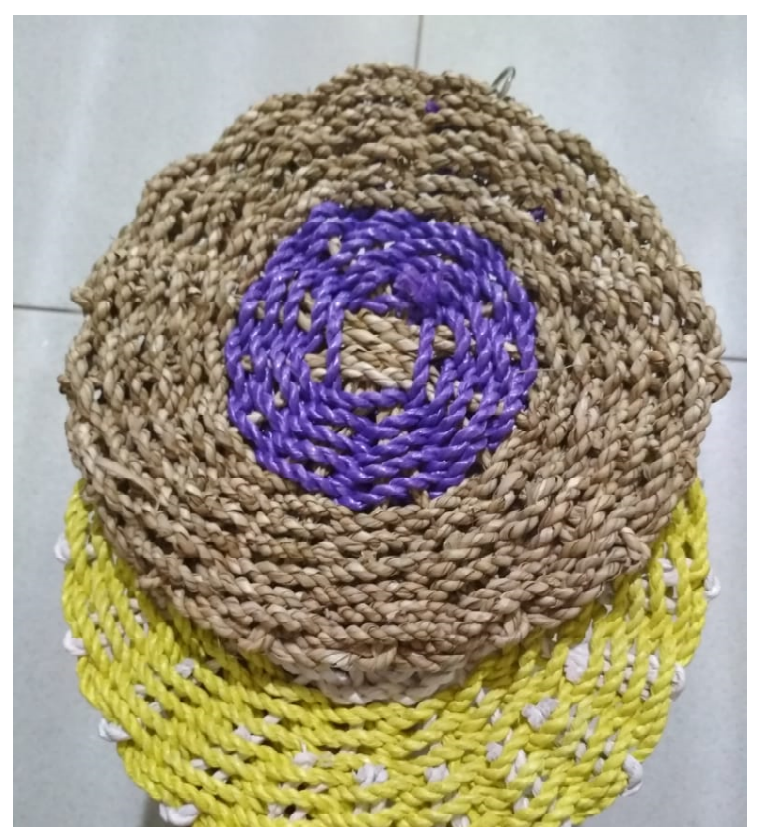

Gambar 9. Luaran berupa tatakan piring dengan material murni dari jerami,

(Foto : Thea, 2019) 


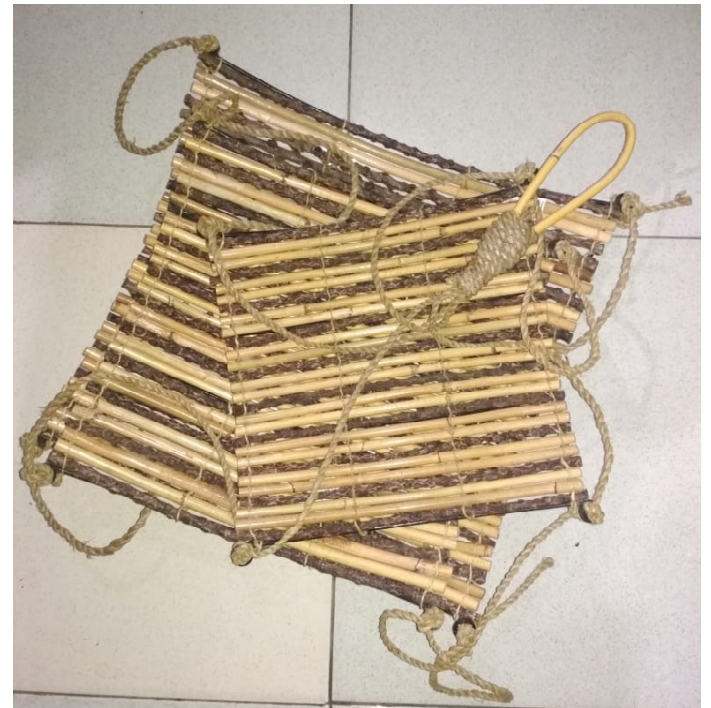

Gambar 10. Luaran berupa rak gantung susun tiga, dengan material jerami dikombinasi dengan ranting dan bambu, (Foto : Thea : 2019).

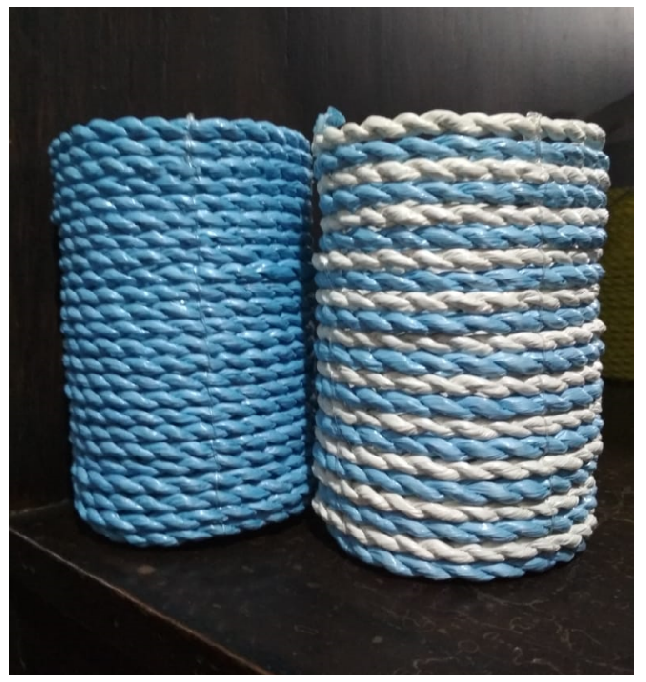

Gambar 11. Luaran berupa tempat pensil berbentuk tabung dengan material murni jerami, (Foto : Thea, 2019)

\section{KESIMPULAN}

Pengabdian kekaryaan ini menghasilkan beberapa beberapa luaran, salah satu dari luaran tersebut adalah dihasilkannya prototipe. Prototipe yang dihasilkan menggunakan material utama jerami yang merupakan material limbah pertanian. Dikatakan limbah karena selama ini pemanfaatan jerami tidak maksimal, artinya bahwa material tersebut banyak digunakan oleh masyarakat setempat guna keperluan sehari-hari, tetapi banyak pula sisa yang lain yang hanya dibakar karena dianggap sebagai barang yang tidak ada manfaatnya dan cenderung mengotori lingkungan.

Demikian pelatihan memanfaatkan jerami ini memiliki fungsi ganda yaitu:

1. Meningkatkan kemampuan mendesain produk kriya berbahan jerami.

2. Termanfaatkannya materila jerami yang lebih efektif sebagai material limbah yang kini dapat difungsikan sebagai material dalam memproduksi karya seni. Selain itu juga dapat memanfaatkan beberapa material lain yang sangat melimpah di desa Tamansari.

3. Meningkatkan kualitas ekonomi masyarakat setempat, sehingga dapat menjadi alternatif memperoleh pendapatan disamping aktifitas keseharian sebagai petani. Bahkan dapat menjadi lapangan kerja yang menjanjikan.

4. Membangun daya kreatifitas baru bagi warga di desa Tamansari, dalam hal pembuatan produk kriya dan sadar wisata

5. Mampu mengikuti perkembangan teknologi informasi melalui internet, dan memanfaatkannya guna menunjang perkembangan desa Tamansari dalam segala bidang.

6. Harapan jangka panjangnya adalah menjadikan Pasar Tradisional kali Buntung sebagai obyek wisata budaya yang dapat mendungkung perkembangan desa Tamansari.

Pengabdian inimenggunakan metode klasik, yaitu dengan mendatangi langsung obyek, berhubungan langsung dengan warga desa Tamansari, baik itu sebagai perajin maupun calon perajin, yang terlebih dahulu di analisis permintaan warga setempat bagaimana keinginan yang diharapkan. Dibekali data dukung dari pemerintah setempat melalui Rukun Tetangga hingga ke tingkat kelurahan dan kecamatan. Dibantu beberapa warga 
setempat yang menjadi mitra dalam pengabdian ini, proses pengabdian dapat berjalan dengan baik. Maka pelatihan kekaryaan dapat dijalani sesuai harapan.

\section{DAFTAR PUSTAKA}

Alfred, Gell. 2005. Anthropology Art and Aesthetics. Clarendon Press, Oxford,

Darsono Sony Kartika. 2016, Kreasi Artistik (perjumpaan tradisi modern dalam paradigma kekaryaan seni, Karanganyar: Citra Sain LPKBN

Hariandja, Marihot Tua Efendi, 2002, Manajemen Sumber Daya Manusia, Grasindo, Jakarta

Karmana, Oman, (2007), Cerdas Belajar Biologi, Grafindo Media Pratama, Bandung

Monroe Beardsley. History of Aesthetics. Dalam The Liang Gie. 2005, Filsafat Keindahan . Edisi II, Yogyakarta: Pusat Belajar Ilmu Berguna (PUBIB)
Nurnitasari, Putri, Tantrina, Aprianita dan Sofiyah. 2009. Menjadi Pengusaha Setelah di PHK. Jakarta: GagasMedia

Papanek, Victor. 1973. Design For The Real World. Toronto, New York, London: Bantam Books, A National General Company

Prakosa, S., Cheon, H.,2013, Thai tourists' souvenir shopping experience in Korea, Asia Marketing Journal 15(3),15-29., ISSN: 1598-7868

Soedarsono, R.M., 2001. Metodologi Seni Pertunjukan dan Seni Rupa, Bandung Masyarakat Seni Pertunjukan Indonesia.

Susilawarno, Gunawan, Et.al. 2007. Biologi Untuk SMA/MA kelas $X$. Jakarta : Grasindo

\section{Sumber Internet :}

https://kbbi.web.id/artistik. https://kbbi.web.id/suvenir https://bisnisukm.com/usaha-kreatif-memproduksicinderamata-khas-pantai.html. 